\title{
Public Expenditure Management and Political Budget Cycles: The Case of Colima City Council 2009-2018
}

\author{
Omar Alejandro Pérez-Cruz ${ }^{1}$, Edgar Alfredo Nande-Vázquez ${ }^{2} \&$ Juan Carlos Martínez-Verdugo ${ }^{3}$ \\ ${ }^{1}$ School of Management and Accounting, Unversity of Colima, México \\ ${ }^{2}$ School of Public Management, Unversity of Colima, México \\ ${ }^{3}$ Division of Economics and Administrative Sciences, Department of Administration, México \\ Correspondence: Omar Alejandro Pérez Cruz, School of Management and Accounting, Unversity of Colima, \\ México. Tel: 52-312-316-1073. E-mail: omar_perez@ucol.mx
}

Received: February 4, 2021

Accepted: March 11, 2021

Online Published: March 15, 2021

doi:10.5539/ijef.v13n4p40

URL: https://doi.org/10.5539/ijef.v13n4p40

\begin{abstract}
The political budget cycles (PBC), as an evolutionary part of the economic political cycle (EPC), demonstrate the existence of opportunistic practices of economic variables, electoral, and budgetary that the politicians in power operate in their management to continue in office. In this sense, the literature suggests a pattern of opportunistic behavior on voters' myopia, showing that there is little retrospective memory for voters, allowing the party in power to execute public policies successfully. Thus, the objective of the research is to analyze the existence of political budgetary cycles in the management of investment spending by the City of Colima from the years 2009 to 2018 . Thus, the objective of the research is to analyze the existence of political budgetary cycles in the management of investment spending by the City of Colima from the years 2009 to 2018. This was analyzed using the panel data methodology (MCO; EF; EA), to estimate the variables dependent on investment and current expenditure, a dummy variable was introduced to identify the year before the election and to be able to control the influence of the electoral period on each regression. The results show that investment spending is related to election periods, population growth, and the federal social aid budget sector. Current expenditure was only related to population growth. This allows us to explain that spending is a resource that finances public works in the states of Mexico. Thus, this research shows that public works is a public expenditure that the states of Mexico apply more in times of elections.
\end{abstract}

Keywords: management, public spending, budget political cycle, dashboard data

\section{Introduction}

The problem of PBC research is manifested in the three levels of government, such as the federal, state, and municipal levels in their respective administrations. It is one of the tools used by the heads of administrations to retain power through the manipulation of economic variables such as current spending and investment spending in an election year: the political budget cycle suggests increases in investment spending and spending of Branch 33 during the year before the elections, it should be to increase the welfare of its citizens, remembering that Branch 33 is provided by the municipal mayors for their use of quality of life to society, a vision that can be used to generate votes in their favor and retain power That is why it has been decided to make an investigation in the municipality of Colima in the period of 2009-2018 to evidence a possible manipulation of economic variables giving a step to the trend of EPC.

The article is divided into 3 sections. In the first one, we find the general theoretical aspects of the research, and later on, we carry out the empirical work to contrast the delimited hypotheses, as well as everything that inquires into the theory of PBC. For the second one, there is the theoretical reference, the conceptual references, and the proposed methodology that was carried out in the research; at the same time, in the last part, there is the analysis of results where it is possible to reflect the different graphs obtained from the unique instrument, the results of the city council of Colima and finally the discussions and conclusions.

\section{Literature Review and Budgetary Political Cycles}

The literature on budgetary political cycles arises from the ruler's interest in manipulating economic, budgetary, and electoral variables, among others, originating manipulation and asymmetries of information for the benefit 
of the rulers in power.

The theory of the EPC postulates that governments execute economic policies influenced by the electoral process (Buchanan, 1967), evidencing public policies that improve the ruler's possibilities of being reelected to remain in power; problems that suggest in the short-term credibility of policies created by the political-institutional environment, distinguishing between informed and uninformed voters, exposed by Shi and Svensson (2006).

Besides, the theory of the PBC supports arguments in the works of Rogoff and Sibert (1988); Rogoff (1990); Persson and Tabellini (2002), suggesting that the incumbent has a temporal advantage of asymmetric information about the voters. These works-maintained Nordhaus (1975) assumption of asymmetries, but from an approach of imperfect information, where governments are heterogeneous in their competitiveness and voters deduct their vote based on their economic performance, among other reasons, mainly in the management of public spending (investment and current).

In that sense, the PBC models of that decade, that is, Nordhaus (1975); Lindbeck (1976); MacRae (1977); Hibbs (1978), considered that the voters' expectations are not rational about the policies that the ruler implements, maintaining voter misinformation.

In this regard, the literature suggests two alternatives about rewarding or punishing the opportunism of the incumbent government: First, the works of Akhmedov and Zhuravskaya (2004); Veiga and Veiga (2007b); Sakurai and Menezes-Filho (2008); Drazen and Eslava (2008); Aidt et al. (2011), argue that the electorate rewards fiscal actions derived from opportunism in elections, while Peltzman (1992); Kraemer (1997); Brender (2003); and Brender and Drazen (2008), lean towards criminalization.

Mejía-Reyes et al. (2016) analyze the characteristics of public spending data to determine the presence of PBC associated with the 1980-2011 State of Mexico gubernatorial elections. The research shows the presence of PBC in administrative spending and public debt and provides episodic evidence of opportunistic behavior in the areas of total spending (1993 election) and transfers (1987 and 1999 elections).

Reyes-Hernández et al. (2019) address the effects of the presidential elections on the spending of Mexico's governments during 1995-2016. The findings show that there is complete evidence of a political budget cycle in total spending and partial evidence in the regional development spending function. Furthermore, they reflect the opportunistic behaviors of the governments to stay in power, as well as the use of public resources as strategies of political patronage; but, on the other hand, it shows how difficult it is to prove their existence.

The current positions of some researchers before the new times indicate a certain aversion to governments in power, ie, the rationality of the voter has changed, and their behavior indicates that the manipulation of the $80 \mathrm{~s}$ and $90 \mathrm{~s}$ in investment spending mainly, no longer exercises the inertia that maintained in those decades.

\section{Research Methodology}

\subsection{Sample an Data}

The sample of this study consisted of information from the works contracts at the Colima City Hall level, in the period from 2009 to 2018. The data were obtained from the following public databases: Banxico, Fortamun, FAIS, INEGI and income statement of the municipality of Colima.

\subsection{Dependent Variable}

To make the estimates on the dependent variables of investment expenditure (IE) and current expenditure (CE), we introduce a control dummy variable to identify the year before the election and thus be able to control the influence of the election period on each regression.

Table 1. Definition of dependent variables

\begin{tabular}{lcrl}
\hline \multicolumn{1}{c}{ Dependent variables } & Coding & & Definition \\
\cline { 1 - 2 } Investment expenditure & IE & $\begin{array}{l}\text { Extensions for the acquisition, construction, expansion, adaptation, and improvement of real } \\
\text { estate (Banxico, 2004). }\end{array}$ \\
Current expenditure & CE & Expenditures that are used to pay salaries and services to personnel (Banxico, 2004). \\
\hline
\end{tabular}

Source: the Authors.

\subsection{Political Budget Cycles Constructs}

Likewise, we complement the equation with three independent variables: population increase (INC_POP), which will determine the increase in investment spending due to natural population growth, Budgetary Branch 33 (BB 33), and the Gross Domestic Product (GDP); the first due to the increase in social spending as a function of 
investment spending, and the second due to demand that positively suggests an increase in services and products produced in the State. In that sense, the variables are shown in the following table.

Table 2. Definition of independent variables

\begin{tabular}{lcllc}
\hline Independent variables & Coding & & Definition & Expected Effect \\
\hline Election year & EY_1 & Dummy of the municipal election cycle (one year before the election). & $+(\mathrm{GI})$ \\
Increase in population & INC_POP & $\begin{array}{l}\text { Increase in population from one year to the next. } \\
\text { Contribution Funds for the Strengthening of Municipalities and }\end{array}$ & + \\
Budgetary Branch 33 & BB33 & $\begin{array}{l}\text { Territorial Demarcations in Mexico City (Fortamun) and Contributions } \\
\text { for Social Infrastructure (FAIS). }\end{array}$ & + \\
Gross Domestic Product & GDP & It is the measurement of a country's economic growth. & + \\
\hline
\end{tabular}

Source: the authors.

\subsection{Regression Model}

One of the methods used for this type of work is panel-type data, which is worked in two dimensions: the cross-sectional observation unit and time series; allowing to improve the reliability of estimates with the fixed-effects (FE) and random-effects (RA) model. Specifically, this paper highlights discerning between the previous models, which is possibly the most complicated problem in the implementation of a panel data model (Sosa, 1999). However, the application of Hausman's test to opt for EF or EA, Wooldridge's for autocorrelation, and Wald's for heteroscedasticity, help and suggest using in the specification of the model to be applied. This type of test is used to detect and control possible problems that the model presents and, besides, they help us to optimize the results that we want to explain.

To determine the existence of autocorrelation and heteroscedasticity in this model, it must adequately reproduce the behavior of the data, so that the innovations must not present autocorrelation and heteroscedasticity. In that sense, the suggested estimator after the contrast of the tests is the corrected standard error panel (EECP), pointed out by Beck (2001) as a powerful model to correct the inconsistencies by the problems if these are detected in the model. The use of the different tests discussed in the methodology will allow us to eliminate as much as possible the heteroscedasticity and autocorrelation not observable in the panel data. In this way the linear model of multiple regression is determined from the two following equations:

$$
\begin{gathered}
\text { Equation 1: } G I_{i t}=\Delta E L_{i t-1}+\mathrm{x}_{1} I_{n c P o b}+\mathrm{x}_{3} R_{-} 33_{i t}+x_{3} P I B+\mu \\
\quad \text { for } i=\text { Colima City Hall } \ldots, \mathrm{y} t=2009 \ldots, 2018 \\
\text { Equation 2: } G C_{i t}=\Delta E L_{i t-1}+\Delta_{2} I_{n c P o b}+\Delta_{3} R_{-} 33_{i t}+\Delta_{4} P I B+\mu \\
\quad \text { for } i=\text { Colima City Hall } \ldots, \mathrm{y} t=2009 \ldots, 2018
\end{gathered}
$$

\subsection{Hypotheses}

Drazen and Eslava (2005) point out in their research on the PBC in public spending, that it consists of affecting its composition in favor of those who reveal to the electorate the supposed fiscal preferences of the incumbent in office. Therefore, this analysis will indicate whether the ruler's decisions regarding the management of spending influence the voter's behavior in the election. In that sense, we try to contrast the following hypotheses:

H1. Investment spending is the preferred way for the ruling party to influence the voter in the pre-election period.

H2. Current spending contracts in the pre-election period, as reflected by increased investment spending.

H3. Natural population growth gradually increases investment spending.

H4. Resources for FORTAMUN and FAIS increase significantly before the election because of the contributions to strengthening and social infrastructure.

H5. GDP has a positive impact on the composition of public spending, due to the relationship between the generation of products and services before the election.

Explain how the research design permits the inferences needed to examine the hypothesis or provide estimates in answer to the question.

\section{Results}

To carry out our analysis we have prepared a panel with 10 observations, which corresponds to the City of Colima 
from 2009 to 2018.

The use of the different tests discussed in the methodology allowed us to eliminate as much as possible the unobservable heterogeneity of the panel, trying to control the individual character of the entity and correct if, the problems of heteroscedasticity and autocorrelation that could present the model. In that sense, we tried to establish the best estimator for panel-type data from the commented tests.

The results of Table 3 show that an $\mathrm{R}^{\wedge} 2$ of 0.7715 is obtained, indicating that the model explains $77.15 \%$ of the total variation in the GI dependent variable.

Table 3. GMM model (Dependent variable investment expenditure / total expenditure)

\begin{tabular}{lcc}
\hline Independent variables & Coefficient & Std.Err \\
\hline EY_1 & $138,94 *$ & 47.051 \\
INC_POP & $0.01845 *$ & 0.005281 \\
BB_33 & $-1.16032 *$ & 0.2165 \\
GDP & -7.9370 & 6.7332 \\
Constant & -1722.016 & 689.6676 \\
\hline R- square & & 0.7715 \\
Number of observations & & 10 \\
Chi-square & & 0,0000 \\
$*$ significant to 1\%** significant to 5\%*** significant to 10\% & \\
\hline Source: Own elaboration with data subtracted from the income statement of the municipality of Colima.
\end{tabular}

On the other hand, the results of the statistical model show that the variables that turned out to be significant were the dichotomous variable that represents the year before the election (EY_1), the population increase (INC_POP), and Branch 33 (BB_33).

Specifically in the variable EL_1 understood as the year before the election, it is significant and presents a positive coefficient. This result, in addition to confirming the hypothesis, suggests that investment spending is indicated by the governor in an attempt to influence the voter.

Likewise, for the variable population increase (INC_POP), its coefficient also presents a positive and significant sign at $1 \%$, which confirms our hypothesis, that is, the increase in population increases investment spending by the government.

For the variable of Budgetary Branch 33 (BB_33), its result is also significant, however, negative, which does not contrast our hypothesis, which could indicate a contraction in the support received for this concept; a trend that is noted in the descriptive analysis with a slight decrease of this resource in the election year, however, an increase in the pre-election year.

For the GDP its coefficient was not significant, it only presents a negative trend, which could suggest a decrease in production and services from 2017 to 2018, the transition of the electoral year. It is important to note that, according to National Institute of Statistics and Geography (INEGI by Spanish acronym) figures, the state of Colima as of 2017 reported annual growth of $4.5 \%$ in GDP, and by 2018 of $2.5 \%$, which represents a decrease of two percentage points from the previous year, which could explain our results.

On the other hand, the results in table 4 show that an $\mathrm{R}^{\wedge} 2$ of 0.7609 is obtained, indicating that the model explains $76.09 \%$ of the total variation in the GC dependent variable.

Table 4. GMM model (Dependent variable current expenditure/total expenditure)

\begin{tabular}{lcc}
\hline Independent variables & Coefficient & Std.Err \\
\hline EY_1 & $-40,4362$ & 171,088 \\
INC_POP & $0,07413 *$ & 0,01733 \\
BB_33 & $-0,970032$ & 0,62276 \\
GDP & $-23,9340$ & 24,78578 \\
Constant & $-7815,19 * *$ & 2309,74 \\
\hline R- square & & 0,7609 \\
Number of observations & & 10 \\
Chi-square & & 0,0000 \\
$*$ significant to $1 \% * *$ significant to 5\%*** significant to $10 \%$ & & \\
\hline
\end{tabular}

Source: Own elaboration with data subtracted from the income statement of the municipality of Colima. 
In this sense, the results of the statistical model show that only the significant variable was the increase in population (INC_POP), which suggests that the ruler, by increasing the population through the increase in required public services, also increases current spending. This is a negative credential for the government since it is a variable that increases the paid weight of the bureaucracy at this level.

For the variable EY_1, we observe a negative coefficient, which is the natural contraction to the increase of EY_1 in GE, however, it is only a trend because it is not significant.

\subsection{Test of Hypotheses}

Hypothesis testing explored the possible association between public spending on investment (IE) and Budgetary Branch (BB33) are used to impress the electorate, that is, as a consequence, the current decreases, varying its behavior about the period of the electoral cycle These hypotheses are tested using regressions whit corrected standard error panel (EECP), as shown in tables 2 and 3. Table 5, shown above below statistically significant distributions, which indicates that IE and CE has associations with GDP.

Table 5. Hypothesis testing

\begin{tabular}{lc}
\hline \multicolumn{1}{c}{ Hypothesis } & Testing \\
\hline H1. Investment spending is the preferred way for the ruling party to influence the voter in the pre-election period. & It's accepted \\
H2. Current spending decreases in the pre-election period in response to increased investment spending. & It's accepted \\
H3. Population growth increases investment spending. & It's accepted \\
H4. BB33 social spending increase before the election. & It's accepted \\
H5. The GDP has a positive impact on the composition of public spending, due to the relationship that exists in the & It's accepted \\
generation of services before the election. &
\end{tabular}

Source: the authors.

In general, as regards the explanatory variables of the two models, there are significant and expected differences in their behavior, that is, firstly, a significant increase in investment spending per capita is observed at the EY_1 level, and, on the other hand, a contraction in the level of current spending; however, for this non-significant case, it would be suggested only as a reflection trend on the investment spending of the variable, commented on in the following conclusions.

\section{Discussion}

This article offers an overview of the effect that elections have on budget management, showing the existence of political budget cycles in investment and current spending in the City of Colima from 2009 to 2018. For this research, we can conclude that, in the municipality of Colima, the elections cause increases in investment spending per inhabitant and a contraction of current spending for total spending.

This leads us to discuss some questions, such as is investment or Branch 33 spending used by the ruling parties to influence the electorate? Do investment and Branch 33 spending increase in the election period? Or does the need for works and services in the municipality increase with the increase in population?

The results obtained show some aspects that help us answer these questions. Recent works in Mexico, such as Gámez and Amarillas (2011) or Ramírez and Erquizio (2012), complement the reflections: the political budget cycle suggests increases in investment spending and Branch 33 spending during the year before the elections, assuming that it should be to increase the welfare of its citizens; however, such an increase - in some cases- is used as a weapon to attract votes and maintain or retain power.

The results are similar in our research and suggestions for the level analyzed an expansion of investment spending per capita, while at the same time a contraction of current spending is produced, trying to seek benefits for the party in power by pointing out its policies.

The above also implies a pattern of opportunistic behavior on the myopia of the voters, who have, according to Gámez and Amarillas (2011), little retrospective memory and allow the party in government to execute opportunistic policies successfully.

Concerning the variation in the population, the results seem to have a greater influence on the IG, since as this variable increases, investment spending increases. The scope of this article was to verify the presence of political budget cycles at the municipal level, and our conclusion points to the evidence presented of the existence of EPC in investment and current spending.

Finally, it is considered important that in subsequent studies the EPC can be analyzed in a disaggregated manner 
with the budgetary programs that make-up program spending, especially about social and education spending, to test a possible relationship in these study variables. It is also important for any level of government to present how and in what way it will exercise its finances so that society is aware of the expenditure it has and the income it receives from the different funds; in what time frame the infrastructure or public policy will be established or carried out.

At the same time, it is believed that the municipal plans presented by the city councilors must be fulfilled within the established period, so if they are not fulfilled on the established date, it allows them to carry out public works or social programs at the end of their period, manipulating the economic variables in their favor, starting a political budget cycle to get more voters to reelection or the party in power. For this reason, one of the solutions that could control the phenomenon of the EPC would be to establish a law initiative to respect the dates and the period established for public works and social programs with only a margin of two to three months after the established date if it is not carried out, to have better control of the economic variables, thus avoiding its manipulation.

\section{References}

Aidt, T. S., Veiga, F. J., \& Veiga, L. G. (2011). Election results and opportunistic policies: A new test of the rational political business cycle model. Public Choice, 148(1-2), 21-44. https://doi.org/10.1007/s11127-010-9644-3

Akhmedov, A., \& Zhuravskaya, E. (2004). Opportunistic political cycles: Test in a young democracy setting. The Quarterly Journal of Economics, 119(4), 1301-1338. https://doi.org/10.1162/0033553042476206

Beck, N. (2001). Time-series-cross-section data: What have we learned in the past few years? Annual Review of Political Science, 4(1), 271-293. https://doi.org/10.1146/annurev.polisci.4.1.271

Brender, A. (2003). The effect of fiscal performance on local government election results in Israel: 1989-1998. Journal of Public Economics, 87(9), 2187-2205. https://doi.org/10.1016/S0047-2727(02)00045-2

Brender, A., \& Drazen, A. (2008). How do budget deficits and economic growth affect reelection prospects? Evidence from a large panel of countries. The American Economic Review, 95(5),2203-2220. https://doi.org/10.1257/aer.98.5.2203

Buchanan, J. M. (1967). La Hacienda pública en un contexto democrático. Madrid: Aguilar.

Drazen, A., \& Eslava, M. (2008). Electoral manipulation via voter-friendly spending: Theory and evidence. Journal of Development Economics, 92(1), 39-52. https://doi.org/10.1016/j.jdeveco.2009.01.001

Gámez, C., \& Amarillas, V. A. (2011). Política económica o economía política: El ciclo político presupuestal en México. Cofactor, II(3),71-96.

Hibbs, D. A. (1987). The American political economy: Macroeconomics and electoral politics in the United States. Harvard University Press.

Kraemer, M. (1997). Electoral Budget Cycles in Latin America and the Caribbean: Incidence, Causes, and Political Futility (No. 4084). Inter-American Development Bank, Research Department. https://doi.org/10.2139/ssrn.1815980

Lindbeck, A. (1976). Stabilization policy in open economies with endogenous politicians. The American Economic Review, 66(2), 1-19.

MacRae, C. D. (1977). A political model of the business cycle. The Journal of Political Economy, 285(2), 39-263. https://doi.org/10.1086/260561

Mejía, R. P., Reyes, H. M. R., \& Melquiades-Ramírez, B. I. (2016). Evidencia de ciclo político presupuestal en el Estado de México. Economía: Teoría y Práctica, 45(1), 1-10.

Nordhaus, W. D. (1975). The political business cycle. The Review of Economic Studies, 42(2), 169-190. https://doi.org/10.2307/2296528

Peltzman, S. (1992). Voters as fiscal conservatives. The Quarterly Journal of Economics, 197(22), 327-361. https://doi.org/10.2307/2118475

Persson, T., \& Tabellini, G. E. (2002). Do electoral cycles differ across political systems? Stockholm University. https://doi.org/10.2139/ssrn.392643

Ramírez, R., \& Erquizio, E. A. (2012). Análisis del ciclo político electoral a partir de variables de gasto público por entidad federativa en México, 1993-2009. Revista de Economía Regional y Sectorial, 4(2), 5-27. 
Reyes Hernández, M. R., Mejía-Reyes, P., \& Mancilla, B. M. (2016). Elecciones presidenciales y el gasto público en desarrollo social en México, 1995 - 2016. Ensayos. Revista de Economía, 38(1), https://doi.org/10.29105/ensayos38.1-2

Rogoff, K. (1990). Equilibrium political budget cycles. American Economic Review, 80(1), 21-36.

Rogoff, K., \& Sibert, A. (1988). Elections and Macroeconomic Policy Cycles. The Review of Economic Studies, 55(1), 1-16. https://doi.org/10.2307/2297526

Sakurai, S. N., \& Menezes-Filho, N. A. (2008). Fiscal policy and reelection in Brazilian municipalities. Public Choice, 137(1-2), 301-314. https://doi.org/10.1007/s11127-008-9329-3

Shi, M., \& Svensson, J. (2006). Political budget cycles: Do they differ across countries and why? Journal of Public Economics, 90(8), 1367-1389. https://doi.org/10.1016/j.jpubeco.2005.09.009

Sosa, E. W. (1999). Tópicos de econometría aplicada (Notas de Clase). Trabajo Docente No. 2, Universidad Nacional de La Plata, 1-78.

\section{Copyrights}

Copyright for this article is retained by the author(s), with first publication rights granted to the journal.

This is an open-access article distributed under the terms and conditions of the Creative Commons Attribution license (http://creativecommons.org/licenses/by/4.0/). 